\title{
1F. Retinoic acid-related orphans (version 2019.4) in the IUPHAR/BPS Guide to Pharmacology Database
}

Anton Jetten ${ }^{1}$, Hong Soon Kang ${ }^{1}$ and Yukimasa Takeda ${ }^{1}$

1. National Institutes of Health, USA

\begin{abstract}
Retinoic acid receptor-related orphan receptors (ROR, nomenclature as agreed by the NC-IUPHAR
\end{abstract}

Subcommittee on Nuclear Hormone Receptors [10]) have yet to be assigned a definitive endogenous ligand, although ROR $\alpha$ may be synthesized with a 'captured' agonist such as cholesterol $[63,62]$.

\section{Contents}

This is a citation summary for $1 \mathrm{~F}$. Retinoic acid-related orphans in the Guide to Pharmacology database (GtoPdb). It exists purely as an adjunct to the database to facilitate the recognition of citations to and from the database by citation analyzers. Readers will almost certainly want to visit the relevant sections of the database which are given here under database links.

GtoPdb is an expert-driven guide to pharmacological targets and the substances that act on them. GtoPdb is a reference work which is most usefully represented as an on-line database. As in any publication this work should be appropriately cited, and the papers it cites should also be recognized. This document provides a citation for the relevant parts of the database, and also provides a reference list for the research cited by those parts.

Please note that the database version for the citations given in GtoPdb are to the most recent preceding version in which the family or its subfamilies and targets were substantially changed. The links below are to the current version. If you need to consult the cited version, rather than the most recent version, please contact the GtoPdb curators.

\section{Database links}

1F. Retinoic acid-related orphans

http://www.guidetopharmacology.org/GRAC/FamilyDisplayForward?familyld=88

Introduction to 1F. Retinoic acid-related orphans

http://www.guidetopharmacology.org/GRAC/FamilylntroductionForward?familyld=88

Receptors

RAR-related orphan receptor- $\alpha$

http://www.guidetopharmacology.org/GRAC/ObjectDisplayForward?objectld=598

RAR-related orphan receptor- $\beta$

http://www.guidetopharmacology.org/GRAC/ObjectDisplayForward?objectld=599

RAR-related orphan receptor- $Y$ 
http://www.guidetopharmacology.org/GRAC/ObjectDisplayForward?objectld=600

\section{References}

1. Aicher TD, Taylor CB and Vanhuis CA. (2016) Aryl dihydro-2h-benzo[b][1,4]oxazine sulfonamide and related compounds for use as agonists of rory and the treatment of disease Patent number: WO2016201225A1.

2. Akashi $M$ and Takumi T. (2005) The orphan nuclear receptor RORalpha regulates circadian transcription of the mammalian core-clock Bmal1. Nat. Struct. Mol. Biol. 12: 441-8 [PMID:15821743]

3. Amstadter AB, Sumner JA, Acierno R, Ruggiero KJ, Koenen KC, Kilpatrick DG, Galea S and Gelernter J. (2013) Support for association of RORA variant and post traumatic stress symptoms in a population-based study of hurricane exposed adults. Mol. Psychiatry 18: 1148-9 [PMID:23319003]

4. André E, Conquet F, Steinmayr M, Stratton SC, Porciatti V and Becker-André M. (1998) Disruption of retinoid-related orphan receptor beta changes circadian behavior, causes retinal degeneration and leads to vacillans phenotype in mice. EMBO J. 17: 3867-77 [PMID:9670004]

5. André E, Gawlas K and Becker-André M. (1998) A novel isoform of the orphan nuclear receptor RORbeta is specifically expressed in pineal gland and retina. Gene 216: 277-83 [PMID:9729429]

6. Ano S, Morishima Y, Ishii Y, Yoh K, Yageta Y, Ohtsuka S, Matsuyama M, Kawaguchi M, Takahashi S and Hizawa N. (2013) Transcription factors GATA-3 and RORyt are important for determining the phenotype of allergic airway inflammation in a murine model of asthma. J. Immunol. 190: 1056-65 [PMID:23293351]

7. Atkins GB, Hu X, Guenther MG, Rachez C, Freedman LP and Lazar MA. (1999) Coactivators for the orphan nuclear receptor RORalpha. Mol. Endocrinol. 13: 1550-7 [PMID:10478845]

8. Becker-André M, André E and DeLamarter JF. (1993) Identification of nuclear receptor mRNAs by RTPCR amplification of conserved zinc-finger motif sequences. Biochem. Biophys. Res. Commun. 194: 13719 [PMID:7916608]

9. Becker-André M, Wiesenberg I, Schaeren-Wiemers N, André E, Missbach M, Saurat JH and Carlberg C. (1994) Pineal gland hormone melatonin binds and activates an orphan of the nuclear receptor superfamily. J. Biol. Chem. 269: 28531-4 [PMID:7961794]

10. Benoit G, Cooney A, Giguere V, Ingraham H, Lazar M, Muscat G, Perlmann T, Renaud JP, Schwabe J, Sladek F, Tsai MJ and Laudet V. (2006) International Union of Pharmacology. LXVI. Orphan nuclear receptors. Pharmacol. Rev. 58: 798-836 [PMID:17132856]

11. Bitsch F, Aichholz R, Kallen J, Geisse S, Fournier B and Schlaeppi JM. (2003) Identification of natural ligands of retinoic acid receptor-related orphan receptor alpha ligand-binding domain expressed in Sf9 cells--a mass spectrometry approach. Anal. Biochem. 323: 139-49 [PMID:14622968]

12. Bordji K, Grillasca JP, Gouze JN, Magdalou J, Schohn H, Keller JM, Bianchi A, Dauça M, Netter P and Terlain B. (2000) Evidence for the presence of peroxisome proliferator-activated receptor (PPAR) alpha and gamma and retinoid $Z$ receptor in cartilage. PPARgamma activation modulates the effects of interleukin-1 beta on rat chondrocytes. J. Biol. Chem. 275: 12243-50 [PMID:10766862]

13. Carlberg C, Hooft van Huijsduijnen R, Staple JK, DeLamarter JF and Becker-André M. (1994) RZRs, a new family of retinoid-related orphan receptors that function as both monomers and homodimers. Mol. Endocrinol. 8: 757-70 [PMID:7935491]

14. Chauvet C, Bois-Joyeux B, Fontaine C, Gervois P, Bernard MA, Staels B and Danan JL. (2005) The gene encoding fibrinogen-beta is a target for retinoic acid receptor-related orphan receptor alpha. Mol.

Endocrinol. 19: 2517-26 [PMID:15941850]

15. Crumbley C, Wang Y, Kojetin DJ and Burris TP. (2010) Characterization of the core mammalian clock component, NPAS2, as a REV-ERBalpha/RORalpha target gene. J. Biol. Chem. 285: 35386-92 [PMID:20817722]

16. Dai J, Choo MK, Park JM and Fisher DE. (2017) Topical ROR Inverse Agonists Suppress Inflammation in Mouse Models of Atopic Dermatitis and Acute Irritant Dermatitis. J. Invest. Dermatol. 137: 2523-2531 [PMID:28774591]

17. Delerive $P$, Chin WW and Suen CS. (2002) Identification of Reverb(alpha) as a novel ROR(alpha) target 
gene. J. Biol. Chem. 277: 35013-8 [PMID:12114512]

18. Devanna $P$ and Vernes SC. (2014) A direct molecular link between the autism candidate gene RORa and the schizophrenia candidate MIR137. Sci Rep 4: 3994 [PMID:24500708]

19. Diefenbach A, Colonna M and Koyasu S. (2014) Development, differentiation, and diversity of innate lymphoid cells. Immunity 41: 354-65 [PMID:25238093]

20. Dong C. (2008) TH17 cells in development: an updated view of their molecular identity and genetic programming. Nat. Rev. Immunol. 8: 337-48 [PMID:18408735]

21. Duez H and Staels B. (2010) Nuclear receptors linking circadian rhythms and cardiometabolic control. Arterioscler. Thromb. Vasc. Biol. 30: 1529-34 [PMID:20631353]

22. Dussault I and Giguère V. (1997) Differential regulation of the N-myc proto-oncogene by ROR alpha and RVR, two orphan members of the superfamily of nuclear hormone receptors. Mol. Cell. Biol. 17: 1860-7 [PMID:9121434]

23. Eberl $G$ and Littman DR. (2004) Thymic origin of intestinal alphabeta T cells revealed by fate mapping of RORgammat+ cells. Science 305: 248-51 [PMID:15247480]

24. Eberl $G$ and Littman DR. (2003) The role of the nuclear hormone receptor RORgammat in the development of lymph nodes and Peyer's patches. Immunol. Rev. 195: 81-90 [PMID:12969312]

25. Eberl G, Marmon S, Sunshine MJ, Rennert PD, Choi Y and Littman DR. (2004) An essential function for the nuclear receptor RORgamma(t) in the generation of fetal lymphoid tissue inducer cells. Nat. Immunol. 5: 64-73 [PMID:14691482]

26. Ersland KM, Christoforou A, Stansberg C, Espeseth T, Mattheisen M, Mattingsdal M, Hardarson GA, Hansen T, Fernandes CP and Giddaluru S et al.. (2012) Gene-based analysis of regionally enriched cortical genes in GWAS data sets of cognitive traits and psychiatric disorders. PLOS ONE 7: e31687 [PMID:22384057]

27. Etain B, Jamain S, Milhiet V, Lajnef M, Boudebesse C, Dumaine A, Mathieu F, Gombert A, Ledudal K and Gard S et al.. (2014) Association between circadian genes, bipolar disorders and chronotypes.Chronobiol. Int. 31: 807-14 [PMID:24716566]

28. Fauber BP and Magnuson S. (2014) Modulators of the nuclear receptor retinoic acid receptor-related orphan receptor-y (RORY or RORc). J. Med. Chem. 57: 5871-92 [PMID:24502334]

29. Fauber BP, René O, Deng Y, DeVoss J, Eidenschenk C, Everett C, Ganguli A, Gobbi A, Hawkins J and Johnson AR et al.. (2015) Discovery of 1-\{4-[3-fluoro-4-((3s,6r)-3-methyl-1,1-dioxo-6-phenyl-[1,2]thiazinan2-ylmethyl)-phenyl]-piperazin-1-yl\}-ethanone (GNE-3500): a potent, selective, and orally bioavailable retinoic acid receptor-related orphan receptor $\mathrm{C}$ (RORc or RORY) inverse agonist. J. Med. Chem. 58: 5308-22 [PMID:26061388]

30. Fitzsimmons RL, Lau P and Muscat GE. (2012) Retinoid-related orphan receptor alpha and the regulation of lipid homeostasis. J. Steroid Biochem. Mol. Biol. 130: 159-68 [PMID:21723946]

31. Flick AC, Jones P, Kaila N, Mente SR, Schnute ME, Trzupek JD, Vazquez ML, Xing L, Zhang L and Wennerstal GM et al.. (2016) Methyl-and trifluoromethyl-substituted pyrrolopyridine modulators of rorc2 and methods of use thereof Patent number: WO2016046755A1.

32. Fu Y, Liu H, Ng L, Kim JW, Hao H, Swaroop A and Forrest D. (2014) Feedback induction of a photoreceptor-specific isoform of retinoid-related orphan nuclear receptor $\beta$ by the rod transcription factor NRL. J. Biol. Chem. 289: 32469-80 [PMID:25296752]

33. Gamboa-Meléndez MA, Huerta-Chagoya A, Moreno-Macías $H$, Vázquez-Cárdenas $P$, Ordóñez-Sánchez ML, Rodríguez-Guillén R, Riba L, Rodríguez-Torres M, Guerra-García MT and Guillén-Pineda LE et al.. (2012) Contribution of common genetic variation to the risk of type 2 diabetes in the Mexican Mestizo population. Diabetes 61: 3314-21 [PMID:22923468]

34. Gege C. (2016) Retinoid-related orphan receptor gamma t (RORYt) inhibitors from Vitae Pharmaceuticals (WO2015116904) and structure proposal for their Phase I candidate VTP-43742. Expert Opin Ther Pat 26: 737-44 [PMID:26895086]

35. Genoux A, Dehondt H, Helleboid-Chapman A, Duhem C, Hum DW, Martin G, Pennacchio LA, Staels B, Fruchart-Najib J and Fruchart JC. (2005) Transcriptional regulation of apolipoprotein A5 gene expression 
by the nuclear receptor RORalpha. Arterioscler. Thromb. Vasc. Biol. 25: 1186-92 [PMID:15790933]

36. Germain P, Staels B, Dacquet C, Spedding M and Laudet V. (2006) Overview of nomenclature of nuclear receptors. Pharmacol. Rev. 58: 685-704 [PMID:17132848]

37. Giguère V, Tini M, Flock G, Ong E, Evans RM and Otulakowski G. (1994) Isoform-specific amino-terminal domains dictate DNA-binding properties of ROR alpha, a novel family of orphan hormone nuclear receptors. Genes Dev. 8: 538-53 [PMID:7926749]

38. Greiner EF, Kirfel J, Greschik H, Huang D, Becker P, Kapfhammer JP and Schüle R. (2000) Differential ligand-dependent protein-protein interactions between nuclear receptors and a neuronal-specific cofactor. Proc. Natl. Acad. Sci. U.S.A. 97: 7160-5 [PMID:10860982]

39. Guillaumond F, Dardente H, Giguère $V$ and Cermakian N. (2005) Differential control of Bmal1 circadian transcription by REV-ERB and ROR nuclear receptors. J. Biol. Rhythms 20: 391-403 [PMID:16267379]

40. Halim TY, MacLaren A, Romanish MT, Gold MJ, McNagny KM and Takei F. (2012) Retinoic-acid-receptorrelated orphan nuclear receptor alpha is required for natural helper cell development and allergic inflammation. Immunity 37: 463-74 [PMID:22981535]

41. Hamilton BA, Frankel WN, Kerrebrock AW, Hawkins TL, FitzHugh W, Kusumi K, Russell LB, Mueller KL, van Berkel V, Birren BW, Kruglyak L and Lander ES. (1996) Disruption of the nuclear hormone receptor RORalpha in staggerer mice. Nature 379: 736-9 [PMID:8602221]

42. Harding HP, Atkins GB, Jaffe AB, Seo WJ and Lazar MA. (1997) Transcriptional activation and repression by RORalpha, an orphan nuclear receptor required for cerebellar development. Mol. Endocrinol. 11: 173746 [PMID:9328355]

43. He YW, Deftos ML, Ojala EW and Bevan MJ. (1998) RORgamma t, a novel isoform of an orphan receptor, negatively regulates Fas ligand expression and IL-2 production in T cells. Immunity 9: 797-806 [PMID:9881970]

44. Hirose T, Smith RJ and Jetten AM. (1994) ROR gamma: the third member of ROR/RZR orphan receptor subfamily that is highly expressed in skeletal muscle. Biochem. Biophys. Res. Commun. 205: 1976-83 [PMID:7811290]

45. Hoorweg K, Peters CP, Cornelissen F, Aparicio-Domingo P, Papazian N, Kazemier G, Mjösberg JM, Spits $\mathrm{H}$ and Cupedo T. (2012) Functional Differences between Human NKp44(-) and NKp44(+) RORC(+) Innate Lymphoid Cells. Front Immuno/ 3: 72 [PMID:22566953]

46. Hu X, Liu X, Moisan J, Wang Y, Lesch CA, Spooner C, Morgan RW, Zawidzka EM, Mertz D and Bousley $D$ et al.. (2016) Synthetic RORY agonists regulate multiple pathways to enhance antitumor immunity. Oncoimmunology 5: e1254854 [PMID:28123897]

47. Hu X, Wang Y, Hao LY, Liu X, Lesch CA, Sanchez BM, Wendling JM, Morgan RW, Aicher TD and Carter LL et al.. (2015) Sterol metabolism controls $T(H) 17$ differentiation by generating endogenous RORY agonists. Nat. Chem. Biol. 11: 141-7 [PMID:25558972]

48. Huang Z, Xie H, Wang R and Sun Z. (2007) Retinoid-related orphan receptor gamma t is a potential therapeutic target for controlling inflammatory autoimmunity. Expert Opin. Ther. Targets 11: 737-43 [PMID:17504012]

49. Huh JR, Leung MW, Huang P, Ryan DA, Krout MR, Malapaka RR, Chow J, Manel N, Ciofani M and Kim SV et al.. (2011) Digoxin and its derivatives suppress TH17 cell differentiation by antagonizing RORYt activity. Nature 472: 486-90 [PMID:21441909]

50. Huh JR and Littman DR. (2012) Small molecule inhibitors of RORyt: targeting Th17 cells and other applications. Eur. J. Immunol. 42: 2232-7 [PMID:22949321]

51. Ivanov II, McKenzie BS, Zhou L, Tadokoro CE, Lepelley A, Lafaille JJ, Cua DJ and Littman DR. (2006) The orphan nuclear receptor RORgammat directs the differentiation program of proinflammatory IL-17+ T helper cells. Cell 126: 1121-33 [PMID:16990136]

52. Ivanov II, Zhou L and Littman DR. (2007) Transcriptional regulation of Th17 cell differentiationSemin. Immunol. 19: 409-17 [PMID:18053739]

53. Jabaudon D, Shnider SJ, Tischfield DJ, Galazo MJ and Macklis JD. (2012) RORß induces barrel-like neuronal clusters in the developing neocortex. Cereb. Cortex 22: 996-1006 [PMID:21799210] 
54. Jaradat M, Stapleton C, Tilley SL, Dixon D, Erikson CJ, McCaskill JG, Kang HS, Angers M, Liao G and Collins $\mathrm{J}$ et al.. (2006) Modulatory role for retinoid-related orphan receptor alpha in allergen-induced lung inflammation. Am. J. Respir. Crit. Care Med. 174: 1299-309 [PMID:16973978]

55. Jetten AM. (2009) Retinoid-related orphan receptors (RORs): critical roles in development, immunity, circadian rhythm, and cellular metabolism. Nucl Recept Signal 7: e003 [PMID:19381306]

56. Jetten AM. (2011) Immunology: A helping hand against autoimmunity. Nature 472: 421-2 [PMID:21525918]

57. Jetten AM. (2004) Recent advances in the mechanisms of action and physiological functions of the retinoid-related orphan receptors (RORs). Curr Drug Targets Inflamm Allergy 3: 395-412 [PMID:15584888]

58. Jetten AM, Kang HS and Takeda Y. (2013) Retinoic acid-related orphan receptors $\alpha$ and $\mathrm{Y}$ : key regulators of lipid/glucose metabolism, inflammation, and insulin sensitivity. Front Endocrinol (Lausanne) 4: 1 [PMID:23355833]

59. Jin L, Martynowski D, Zheng S, Wada T, Xie W and Li Y. (2010) Structural basis for hydroxycholesterols as natural ligands of orphan nuclear receptor RORgamma. Mol. Endocrinol. 24: 923-9 [PMID:20203100]

60. Johnson DR, Lovett JM, Hirsch M, Xia F and Chen JD. (2004) NuRD complex component Mi-2beta binds to and represses RORgamma-mediated transcriptional activation. Biochem. Biophys. Res. Commun. 318: 714-8 [PMID:15144897]

61. Jolly S, Journiac N, Naudet F, Gautheron V, Mariani J and Vernet-der Garabedian B. (2011) Cellautonomous and non-cell-autonomous neuroprotective functions of ROR $\alpha$ in neurons and astrocytes during hypoxia. J. Neurosci. 31: 14314-23 [PMID:21976517]

62. Kallen J, Schlaeppi JM, Bitsch F, Delhon I and Fournier B. (2004) Crystal structure of the human RORalpha Ligand binding domain in complex with cholesterol sulfate at 2.2 A. J. Biol. Chem. 279: 14033-8 [PMID:14722075]

63. Kallen JA, Schlaeppi JM, Bitsch F, Geisse S, Geiser M, Delhon I and Fournier B. (2002) X-ray structure of the hRORalpha LBD at $1.63 \mathrm{~A}$ : structural and functional data that cholesterol or a cholesterol derivative is the natural ligand of RORalpha. Structure 10: 1697-707 [PMID:12467577]

64. Kang HS, Angers M, Beak JY, Wu X, Gimble JM, Wada T, Xie W, Collins JB, Grissom SF and Jetten AM. (2007) Gene expression profiling reveals a regulatory role for ROR alpha and ROR gamma in phase I and phase II metabolism. Physiol. Genomics 31: 281-94 [PMID:17666523]

65. Kang HS, Okamoto K, Takeda Y, Beak JY, Gerrish K, Bortner CD, DeGraff LM, Wada T, Xie W and Jetten AM. (2011) Transcriptional profiling reveals a role for RORalpha in regulating gene expression in obesityassociated inflammation and hepatic steatosis. Physiol. Genomics 43: 818-28 [PMID:21540300]

66. Kiss EA and Diefenbach A. (2012) Role of the Aryl Hydrocarbon Receptor in Controlling Maintenance and Functional Programs of RORyt(+) Innate Lymphoid Cells and Intraepithelial Lymphocytes. Front Immunol 3: 124 [PMID:22666222]

67. Kojetin DJ and Burris TP. (2014) REV-ERB and ROR nuclear receptors as drug targets.Nat Rev Drug Discov 13: 197-216 [PMID:24577401]

68. Kono M, Ochida A, Oda T, Imada T, Banno Y, Taya N, Masada S, Kawamoto T, Yonemori K and Nara Y et al.. (2018) Discovery of [ cis-3-(\{(5 R)-5-[(7-Fluoro-1,1-dimethyl-2,3-dihydro-1 H-inden-5-yl)carbamoyl]2-methoxy-7,8-dihydro-1,6-naphthyridin-6(5 H)-yl\}carbonyl)cyclobutyl]acetic Acid (TAK-828F) as a Potent, Selective, and Orally Available Novel Retinoic Acid Receptor-Related Orphan Receptor yt Inverse Agonist. J. Med. Chem. 61: 2973-2988 [PMID:29510038]

69. Kumar N, Solt LA, Conkright JJ, Wang Y, Istrate MA, Busby SA, Garcia-Ordonez RD, Burris TP and Griffin PR. (2010) The benzenesulfoamide T0901317 [N-(2,2,2-trifluoroethyl)-N-[4-[2,2,2-trifluoro-1-hydroxy-1(trifluoromethyl)ethyl]phenyl]-benzenesulfonamide] is a novel retinoic acid receptor-related orphan receptor-alpha/gamma inverse agonist. Mol. Pharmacol. 77: 228-36 [PMID:19887649]

70. Kurebayashi S, Nakajima T, Kim SC, Chang CY, McDonnell DP, Renaud JP and Jetten AM. (2004) Selective LXXLL peptides antagonize transcriptional activation by the retinoid-related orphan receptor RORgamma. Biochem. Biophys. Res. Commun. 315: 919-27 [PMID:14985100]

71. Kurebayashi S, Ueda E, Sakaue M, Patel DD, Medvedev A, Zhang F and Jetten AM. (2000) Retinoidrelated orphan receptor gamma (RORgamma) is essential for lymphoid organogenesis and controls 
apoptosis during thymopoiesis. Proc. Natl. Acad. Sci. U.S.A. 97: 10132-7 [PMID:10963675]

72. Lau P, Bailey P, Dowhan DH and Muscat GE. (1999) Exogenous expression of a dominant negative RORalpha1 vector in muscle cells impairs differentiation: RORalpha1 directly interacts with $\mathrm{p} 300$ and myoD. Nucleic Acids Res. 27: 411-20 [PMID:9862959]

73. Lau P, Fitzsimmons RL, Pearen MA, Watt MJ and Muscat GE. (2011) Homozygous staggerer (sg/sg) mice display improved insulin sensitivity and enhanced glucose uptake in skeletal muscle. Diabetologia 54: 1169-80 [PMID:21279323]

74. Lau P, Fitzsimmons RL, Raichur S, Wang SC, Lechtken A and Muscat GE. (2008) The orphan nuclear receptor, RORalpha, regulates gene expression that controls lipid metabolism: staggerer (SG/SG) mice are resistant to diet-induced obesity. J. Biol. Chem. 283: 18411-21 [PMID:18441015]

75. Lee JM, Kim IS, Kim H, Lee JS, Kim K, Yim HY, Jeong J, Kim JH, Kim JY, Lee H, Seo SB, Kim H, Rosenfeld MG, Kim KI and Baek SH. (2010) RORalpha attenuates Wnt/beta-catenin signaling by PKCalpha-dependent phosphorylation in colon cancer. Mol. Cell 37: 183-95 [PMID:20122401]

76. Liu H, Kim SY, Fu Y, Wu X, Ng L, Swaroop A and Forrest D. (2013) An isoform of retinoid-related orphan receptor $\beta$ directs differentiation of retinal amacrine and horizontal interneurons. Nat Commun 4: 1813 [PMID:23652001]

77. Logue MW, Baldwin C, Guffanti G, Melista E, Wolf EJ, Reardon AF, Uddin M, Wildman D, Galea S and Koenen KC et al.. (2013) A genome-wide association study of post-traumatic stress disorder identifies the retinoid-related orphan receptor alpha (RORA) gene as a significant risk locus. Mol. Psychiatry 18: 937-42 [PMID:22869035]

78. Marciano DP, Chang MR, Corzo CA, Goswami D, Lam VQ, Pascal BD and Griffin PR. (2014) The therapeutic potential of nuclear receptor modulators for treatment of metabolic disorders: PPARY, RORs, and Rev-erbs. Cell Metab. 19: 193-208 [PMID:24440037]

79. Matsui T. (1996) Differential activation of the murine laminin B1 gene promoter by RAR alpha, ROR alpha, and AP-1. Biochem. Biophys. Res. Commun. 220: 405-10 [PMID:8645318]

80. Matsumura R, Matsubara C, Node K, Takumi T and Akashi M. (2013) Nuclear receptor-mediated cellautonomous oscillatory expression of the circadian transcription factor, neuronal PAS domain protein 2 (NPAS2). J. Biol. Chem. 288: 36548-53 [PMID:24196956]

81. Matysiak-Scholze $U$ and Nehls M. (1997) The structural integrity of ROR alpha isoforms is mutated in staggerer mice: cerebellar coexpression of ROR alpha1 and ROR alpha4. Genomics 43: 78-84 [PMID:9226375]

82. McBroom LD, Flock G and Giguère V. (1995) The nonconserved hinge region and distinct amino-terminal domains of the ROR alpha orphan nuclear receptor isoforms are required for proper DNA bending and ROR alpha-DNA interactions. Mol. Cell. Biol. 15: 796-808 [PMID:7823947]

83. McKenzie AN, Spits $\mathrm{H}$ and Eberl G. (2014) Innate lymphoid cells in inflammation and immunity.Immunity 41: 366-74 [PMID:25238094]

84. Medvedev A, Yan ZH, Hirose T, Giguère V and Jetten AM. (1996) Cloning of a cDNA encoding the murine orphan receptor RZR/ROR gamma and characterization of its response element. Gene 181: 199-206 [PMID:8973331]

85. Meissburger B, Ukropec J, Roeder E, Beaton N, Geiger M, Teupser D, Civan B, Langhans W, Nawroth PP and Gasperikova $D$ et al.. (2011) Adipogenesis and insulin sensitivity in obesity are regulated by retinoidrelated orphan receptor gamma. EMBO Mol Med 3: 637-51 [PMID:21853531]

86. Melén E, Kho AT, Sharma S, Gaedigk R, Leeder JS, Mariani TJ, Carey VJ, Weiss ST and Tantisira KG. (2011) Expression analysis of asthma candidate genes during human and murine lung development. Respir. Res. 12: 86 [PMID:21699702]

87. Meyer T, Kneissel M, Mariani J and Fournier B. (2000) In vitro and in vivo evidence for orphan nuclear receptor RORalpha function in bone metabolism. Proc. Natl. Acad. Sci. U.S.A. 97: 9197-202 [PMID:10900268]

88. Miller MW, Wolf EJ, Logue MW and Baldwin CT. (2013) The retinoid-related orphan receptor alpha (RORA) gene and fear-related psychopathology. J Affect Disord 151: 702-8 [PMID:24007783] 
89. Moffatt MF, Gut IG, Demenais F, Strachan DP, Bouzigon E, Heath S, von Mutius E, Farrall M, Lathrop M and Cookson WO et al.. (2010) A large-scale, consortium-based genomewide association study of asthma. N. Engl. J. Med. 363: 1211-21 [PMID:20860503]

90. Mongrain V, Ruan X, Dardente H, Fortier EE and Cermakian N. (2008) Clock-dependent and independent transcriptional control of the two isoforms from the mouse Rorgamma gene. Genes Cells 13: 1197-210 [PMID:19076641]

91. Moraitis AN, Giguère V and Thompson CC. (2002) Novel mechanism of nuclear receptor corepressor interaction dictated by activation function 2 helix determinants. Mol. Cell. Biol. 22: 6831-41 [PMID:12215540]

92. Mukherji A, Kobiita A, Ye T and Chambon P. (2013) Homeostasis in intestinal epithelium is orchestrated by the circadian clock and microbiota cues transduced by TLRs. Cell 153: 812-27 [PMID:23663780]

93. Nakajima Y, Ikeda M, Kimura T, Honma S, Ohmiya Y and Honma K. (2004) Bidirectional role of orphan nuclear receptor RORalpha in clock gene transcriptions demonstrated by a novel reporter assay system. FEBS Lett. 565: 122-6 [PMID:15135064]

94. Nguyen A, Rauch TA, Pfeifer GP and Hu VW. (2010) Global methylation profiling of lymphoblastoid cell lines reveals epigenetic contributions to autism spectrum disorders and a novel autism candidate gene, RORA, whose protein product is reduced in autistic brain. FASEB J. 24: 3036-51 [PMID:20375269]

95. Noguchi M, Nomura A, Murase K, Doi S, Yamaguchi K, Hirata K, Shiozaki M, Hirashima S, Kotoku M and Yamaguchi T et al.. (2017) Ternary complex of human RORy ligand-binding domain, inverse agonist and SMRT peptide shows a unique mechanism of corepressor recruitment. Genes Cells 22: 535-551 [PMID:28493531]

96. Nurieva R, Yang XO, Martinez G, Zhang Y, Panopoulos AD, Ma L, Schluns K, Tian Q, Watowich SS and Jetten AM et al.. (2007) Essential autocrine regulation by IL-21 in the generation of inflammatory T cells. Nature 448: 480-3 [PMID:17581589]

97. Ortiz MA, Piedrafita FJ, Pfahl M and Maki R. (1995) TOR: a new orphan receptor expressed in the thymus that can modulate retinoid and thyroid hormone signals. Mol. Endocrinol. 9: 1679-91 [PMID:8614404]

98. Ou Z, Shi X, Gilroy RK, Kirisci L, Romkes M, Lynch C, Wang H, Xu M, Jiang M and Ren Set al.. (2013) Regulation of the human hydroxysteroid sulfotransferase (SULT2A1) by ROR $\alpha$ and RORY and its potential relevance to human liver diseases. Mol. Endocrinol. 27: 106-15 [PMID:23211525]

99. Paravicini G, Steinmayr M, André E and Becker-André M. (1996) The metastasis suppressor candidate nucleotide diphosphate kinase NM23 specifically interacts with members of the ROR/RZR nuclear orphan receptor subfamily. Biochem. Biophys. Res. Commun. 227: 82-7 [PMID:8858107]

100. Pathak P, Li T and Chiang JY. (2013) Retinoic acid-related orphan receptor $\alpha$ regulates diurnal rhythm and fasting induction of sterol 12 $\alpha$-hydroxylase in bile acid synthesis. J. Biol. Chem. 288: 37154-65 [PMID:24226095]

101. Raichur S, Fitzsimmons RL, Myers SA, Pearen MA, Lau P, Eriksson N, Wang SM and Muscat GE. (2010) Identification and validation of the pathways and functions regulated by the orphan nuclear receptor, ROR alpha1, in skeletal muscle. Nucleic Acids Res. 38: 4296-312 [PMID:20338882]

102. Raichur S, Lau P, Staels B and Muscat GE. (2007) Retinoid-related orphan receptor gamma regulates several genes that control metabolism in skeletal muscle cells: links to modulation of reactive oxygen species production. J. Mol. Endocrinol. 39: 29-44 [PMID:17601883]

103. Ramasamy A, Kuokkanen M, Vedantam S, Gajdos ZK, Couto Alves A, Lyon HN, Ferreira MA, Strachan DP, Zhao JH and Abramson MJ et al.. (2012) Genome-wide association studies of asthma in populationbased cohorts confirm known and suggested loci and identify an additional association near HLA. PLOS ONE 7: e44008 [PMID:23028483]

104. Raspè E, Mautino G, Duval C, Fontaine C, Duez H, Barbier O, Monte D, Fruchart J, Fruchart JC and Staels B. (2002) Transcriptional regulation of human Rev-erbalpha gene expression by the orphan nuclear receptor retinoic acid-related orphan receptor alpha. J. Biol. Chem. 277: 49275-81 [PMID:12377782]

105. Salimi M, Barlow JL, Saunders SP, Xue L, Gutowska-Owsiak D, Wang X, Huang LC, Johnson D, Scanlon ST and McKenzie AN et al.. (2013) A role for IL-25 and IL-33-driven type-2 innate lymphoid cells in atopic 
dermatitis. J. Exp. Med. 210: 2939-50 [PMID:24323357]

106. Santarlasci V, Maggi L, Capone M, Querci V, Beltrame L, Cavalieri D, D'Aiuto E, Cimaz R, Nebbioso A and Liotta $\mathrm{F}$ et al.. (2012) Rarity of human T helper 17 cells is due to retinoic acid orphan receptor-dependent mechanisms that limit their expansion. Immunity 36: 201-14 [PMID:22326581]

107. Santori FR, Huang P, van de Pavert SA, Douglass Jr EF, Leaver DJ, Haubrich BA, Keber R, Lorbek G, Konijn T and Rosales BN et al.. (2015) Identification of natural RORy ligands that regulate the development of lymphoid cells. Cell Metab. 21: 286-97 [PMID:25651181]

108. Sarachana T and Hu VW. (2013) Genome-wide identification of transcriptional targets of RORA reveals direct regulation of multiple genes associated with autism spectrum disorder. Mol Autism 4: 14 [PMID:23697635]

109. Sarachana T and Hu VW. (2013) Differential recruitment of coregulators to the RORA promoter adds another layer of complexity to gene (dys) regulation by sex hormones in autism. Mol Autism 4: 39 [PMID:24119295]

110. Sarachana $T, X u M, W u R C$ and Hu VW. (2011) Sex hormones in autism: androgens and estrogens differentially and reciprocally regulate RORA, a novel candidate gene for autism. PLOS ONE 6: e17116 [PMID:21359227]

111. Sato TK, Panda S, Miraglia LJ, Reyes TM, Rudic RD, McNamara P, Naik KA, FitzGerald GA, Kay SA and Hogenesch JB. (2004) A functional genomics strategy reveals Rora as a component of the mammalian circadian clock. Neuron 43: 527-37 [PMID:15312651]

112. Schaeren-Wiemers N, André E, Kapfhammer JP and Becker-André M. (1997) The expression pattern of the orphan nuclear receptor RORbeta in the developing and adult rat nervous system suggests a role in the processing of sensory information and in circadian rhythm. Eur. J. Neurosci. 9: 2687-701 [PMID:9517474]

113. Schnute ME, Wennerstål M, Alley J, Bengtsson M, Blinn JR, Bolten CW, Braden T, Bonn T, Carlsson B and Caspers $\mathrm{N}$ et al.. (2018) Discovery of 3-Cyano- N-(3-(1-isobutyrylpiperidin-4-yl)-1-methyl-4(trifluoromethyl)-1 H-pyrrolo[2,3- b]pyridin-5-yl)benzamide: A Potent, Selective, and Orally Bioavailable Retinoic Acid Receptor-Related Orphan Receptor C2 Inverse Agonist. J. Med. Chem. 61: 10415-10439 [PMID:30130103]

114. Serafini N, Klein Wolterink RG, Satoh-Takayama N, Xu W, Vosshenrich CA, Hendriks RW and Di Santo JP. (2014) Gata3 drives development of RORyt+ group 3 innate lymphoid cells. J. Exp. Med. 211: 199-208 [PMID:24419270]

115. Skepner J, Ramesh R, Trocha M, Schmidt D, Baloglu E, Lobera M, Carlson T, Hill J, Orband-Miller LA and Barnes A et al.. (2014) Pharmacologic inhibition of RORyt regulates Th17 signature gene expression and suppresses cutaneous inflammation in vivo. J. Immunol. 192: 2564-75 [PMID:24516202]

116. Slominski AT, Kim TK, Takeda Y, Janjetovic Z, Brozyna AA, Skobowiat C, Wang J, Postlethwaite A, Li W and Tuckey RC et al.. (2014) ROR $\alpha$ and ROR $y$ are expressed in human skin and serve as receptors for endogenously produced noncalcemic 20-hydroxy- and 20,23-dihydroxyvitamin D. FASEB J. 28: 2775-89 [PMID:24668754]

117. Smith SH, Peredo CE, Takeda Y, Bui T, Neil J, Rickard D, Millerman E, Therrien JP, Nicodeme E and Brusq JM et al.. (2016) Development of a Topical Treatment for Psoriasis Targeting RORY: From Bench to Skin. PLoS ONE 11: e0147979 [PMID:26870941]

118. Solt LA, Banerjee S, Campbell S, Kamenecka TM and Burris TP. (2015) ROR inverse agonist suppresses insulitis and prevents hyperglycemia in a mouse model of type 1 diabetes. Endocrinology 156: 869-81 [PMID:25560829]

119. Solt LA and Burris TP. (2012) Action of RORs and their ligands in (patho)physiology.Trends Endocrinol. Metab. 23: 619-27 [PMID:22789990]

120. Solt LA, Kojetin DJ and Burris TP. (2011) The REV-ERBs and RORs: molecular links between circadian rhythms and lipid homeostasis. Future Med Chem 3: 623-38 [PMID:21526899]

121. Solt LA, Kumar N, Nuhant P, Wang Y, Lauer JL, Liu J, Istrate MA, Kamenecka TM, Roush WR and Vidović $\mathrm{D}$ et al.. (2011) Suppression of TH17 differentiation and autoimmunity by a synthetic ROR ligand. 
Nature 472: 491-4 [PMID:21499262]

122. Song Y, Xue X, Wu X, Wang R, Xing Y, Yan W, Zhou Y, Qian CN, Zhang Y and Xu Y. (2016) Identification of N-phenyl-2-(N-phenylphenylsulfonamido)acetamides as new RORY inverse agonists: Virtual screening, structure-based optimization, and biological evaluation. Eur J Med Chem 116: 13-26 [PMID:27043267]

123. Stehlin C, Wurtz JM, Steinmetz A, Greiner E, Schüle R, Moras D and Renaud JP. (2001) X-ray structure of the orphan nuclear receptor RORbeta ligand-binding domain in the active conformation. EMBO J. 20 : 5822-31 [PMID:11689423]

124. Stehlin-Gaon C, Willmann D, Zeyer D, Sanglier S, Van Dorsselaer A, Renaud JP, Moras D and Schüle R. (2003) All-trans retinoic acid is a ligand for the orphan nuclear receptor ROR beta. Nat. Struct. Biol. 10: 820-5 [PMID:12958591]

125. Steinmayr M, André E, Conquet F, Rondi-Reig L, Delhaye-Bouchaud N, Auclair N, Daniel H, Crépel F, Mariani J, Sotelo $C$ and Becker-André M. (1998) staggerer phenotype in retinoid-related orphan receptor alpha-deficient mice. Proc. Natl. Acad. Sci. U.S.A. 95: 3960-5 [PMID:9520475]

126. Strausberg RL, Feingold EA, Grouse LH, Derge JG, Klausner RD, Collins FS, Wagner L, Shenmen CM, Schuler GD and Altschul SF et al.. (2002) Generation and initial analysis of more than 15,000 full-length human and mouse cDNA sequences. Proc. Natl. Acad. Sci. U.S.A. 99: 16899-903 [PMID:12477932]

127. Sun Z, Unutmaz D, Zou YR, Sunshine MJ, Pierani A, Brenner-Morton S, Mebius RE and Littman DR. (2000) Requirement for RORgamma in thymocyte survival and lymphoid organ development. Science 288: 2369-73 [PMID:10875923]

128. Takeda $Y$ and Jetten AM. (2013) Prospero-related homeobox 1 (Prox1) functions as a novel modulator of retinoic acid-related orphan receptors $\alpha$ - and $y$-mediated transactivation. Nucleic Acids Res. 41: 69927008 [PMID:23723244]

129. Takeda $Y$, Jothi $R$, Birault $V$ and Jetten AM. (2012) RORY directly regulates the circadian expression of clock genes and downstream targets in vivo. Nucleic Acids Res. 40: 8519-35 [PMID:22753030]

130. Takeda $Y$, Kang HS, Angers $M$ and Jetten AM. (2011) Retinoic acid-related orphan receptor $Y$ directly regulates neuronal PAS domain protein 2 transcription in vivo. Nucleic Acids Res. 39: 4769-82 [PMID:21317191]

131. Takeda Y, Kang HS, Freudenberg J, DeGraff LM, Jothi R and Jetten AM. (2014) Retinoic acid-related orphan receptor $Y$ (RORY): a novel participant in the diurnal regulation of hepatic gluconeogenesis and insulin sensitivity. PLoS Genet. 10: e1004331 [PMID:24831725]

132. Takeda Y, Kang HS, Lih FB, Jiang H, Blaner WS and Jetten AM. (2014) Retinoid acid-related orphan receptor $\mathrm{Y}, \mathrm{ROR}$, participates in diurnal transcriptional regulation of lipid metabolic genes. Nucleic Acids Res. 42: 10448-59 [PMID:25143535]

133. Tilley SL, Jaradat M, Stapleton C, Dixon D, Hua X, Erikson CJ, McCaskill JG, Chason KD, Liao G and Jania $L$ et al.. (2007) Retinoid-related orphan receptor gamma controls immunoglobulin production and Th1/Th2 cytokine balance in the adaptive immune response to allergen. J. Immunol. 178: 3208-18 [PMID:17312169]

134. Tinahones FJ, Moreno-Santos I, Vendrell J, Chacon MR, Garrido-Sanchez L, García-Fuentes E and Macias-González M. (2012) The retinoic acid receptor-related orphan nuclear receptor Y1 (RORY1): a novel player determinant of insulin sensitivity in morbid obesity. Obesity (Silver Spring) 20: 488-97 [PMID:21904299]

135. Tini M, Fraser RA and Giguère V. (1995) Functional interactions between retinoic acid receptor-related orphan nuclear receptor (ROR alpha) and the retinoic acid receptors in the regulation of the gamma Fcrystallin promoter. J. Biol. Chem. 270: 20156-61 [PMID:7650034]

136. Tuong ZK, Lau P, Yeo JC, Pearen MA, Wall AA, Stanley AC, Stow JL and Muscat GE. (2013) Disruption of Rora1 and cholesterol 25-hydroxylase expression attenuates phagocytosis in male Rorasg/sg mice. Endocrinology 154: 140-9 [PMID:23239817]

137. van de Pavert SA, Ferreira M, Domingues RG, Ribeiro H, Molenaar R, Moreira-Santos L, Almeida FF, Ibiza S, Barbosa I and Goverse G et al.. (2014) Maternal retinoids control type 3 innate lymphoid cells and set the offspring immunity. Nature 508: 123-7 [PMID:24670648] 
138. van Niel MB, Fauber BP, Cartwright M, Gaines S, Killen JC, René O, Ward SI, de Leon Boenig G, Deng Y and Eidenschenk $C$ et al.. (2014) A reversed sulfonamide series of selective RORc inverse agonists.

Bioorg. Med. Chem. Lett. 24: 5769-76 [PMID:25453817]

139. Wada T, Kang HS, Angers M, Gong H, Bhatia S, Khadem S, Ren S, Ellis E, Strom SC and Jetten ANet al.. (2008) Identification of oxysterol 7alpha-hydroxylase (Cyp7b1) as a novel retinoid-related orphan receptor alpha (RORalpha) (NR1F1) target gene and a functional cross-talk between RORalpha and liver X receptor (NR1H3). Mol. Pharmacol. 73: 891-9 [PMID:18055760]

140. Walker JA, Barlow JL and McKenzie AN. (2013) Innate lymphoid cells--how did we miss them?Nat. Rev. Immunol. 13: 75-87 [PMID:23292121]

141. Wang Y, Kumar N, Crumbley C, Griffin PR and Burris TP. (2010) A second class of nuclear receptors for oxysterols: Regulation of RORalpha and RORgamma activity by $24 \mathrm{~S}$-hydroxycholesterol (cerebrosterol). Biochim. Biophys. Acta 1801: 917-23 [PMID:20211758]

142. Wang Y, Kumar N, Solt LA, Richardson TI, Helvering LM, Crumbley C, Garcia-Ordonez RD, Stayrook KR, Zhang $X$ and Novick S et al.. (2010) Modulation of retinoic acid receptor-related orphan receptor alpha and gamma activity by 7-oxygenated sterol ligands. J. Biol. Chem. 285: 5013-25 [PMID:19965867]

143. Wang Y, Solt LA and Burris TP. (2010) Regulation of FGF21 expression and secretion by retinoic acid receptor-related orphan receptor alpha. J. Biol. Chem. 285: 15668-73 [PMID:20332535]

144. Wiesenberg I, Missbach M, Kahlen JP, Schräder M and Carlberg C. (1995) Transcriptional activation of the nuclear receptor RZR alpha by the pineal gland hormone melatonin and identification of CGP 52608 as a synthetic ligand. Nucleic Acids Res. 23: 327-33 [PMID:7885826]

145. Wong SH, Walker JA, Jolin HE, Drynan LF, Hams E, Camelo A, Barlow JL, Neill DR, Panova V and Koch $U$ et al.. (2012) Transcription factor ROR $\alpha$ is critical for nuocyte development.Nat. Immunol. 13: 229-36 [PMID:22267218]

146. Xiao S, Yosef N, Yang J, Wang Y, Zhou L, Zhu C, Wu C, Baloglu E, Schmidt D and Ramesh Pet al.. (2014) Small-molecule RORyt antagonists inhibit T helper 17 cell transcriptional network by divergent mechanisms. Immunity 40: 477-89 [PMID:24745332]

147. Xu T, Wang X, Zhong B, Nurieva RI, Ding S and Dong C. (2011) Ursolic acid suppresses interleukin-17 (IL-17) production by selectively antagonizing the function of RORgamma t protein. J. Biol. Chem. 286: 22707-10 [PMID:21566134]

148. Yang XO, Pappu BP, Nurieva R, Akimzhanov A, Kang HS, Chung Y, Ma L, Shah B, Panopoulos AD and Schluns KS et al.. (2008) T helper 17 lineage differentiation is programmed by orphan nuclear receptors ROR alpha and ROR gamma. Immunity 28: 29-39 [PMID:18164222]

149. Yosef N, Shalek AK, Gaublomme JT, Jin H, Lee Y, Awasthi A, Wu C, Karwacz K, Xiao S and Jorgolli Net al.. (2013) Dynamic regulatory network controlling TH17 cell differentiation.Nature 496: 461-8 [PMID:23467089]

150. Yu X, Rollins D, Ruhn KA, Stubblefield JJ, Green CB, Kashiwada M, Rothman PB, Takahashi JS and Hooper LV. (2013) TH17 cell differentiation is regulated by the circadian clock. Science 342: 727-30 [PMID:24202171]

151. Zhang F, Meng G and Strober W. (2008) Interactions among the transcription factors Runx1, RORgammat and Foxp3 regulate the differentiation of interleukin 17-producing T cells. Nat. Immunol. 9: 1297-306 [PMID:18849990]

152. Zhao X, Graves C, Ames SJ, Fisher DE and Spanjaard RA. (2009) Mechanism of regulation and suppression of melanoma invasiveness by novel retinoic acid receptor-gamma target gene carbohydrate sulfotransferase 10. Cancer Res. 69: 5218-25 [PMID:19470764] 